\title{
A model on biological flow of phosphorus in growing pigs
}

\author{
[Modelo do fluxo do fósforo em suínos na fase de crescimento]
}

\author{
J.B. Lopes $^{1}$, J.A. Moreira ${ }^{2 *}$, E. Kebreab ${ }^{2,3}$, D.M.S.S. Vitti ${ }^{4}$, A.L. Abdalla ${ }^{4}$, \\ L.A. Crompton ${ }^{3}$, J. France ${ }^{3}$ \\ ${ }^{1}$ Centro de Ciências Agrárias - UFPI - Teresina, PI \\ ${ }^{2}$ Department of Animal and Plant Science - University of Manitoba - Winnipeg - Manitoba, Canada \\ ${ }^{3}$ Department of Animal \& Poutry Science - University of Guelph - Guelph - Ontário, Canada \\ ${ }^{4}$ Centro de Energia Nuclear na Agricultura - Piracicaba, SP
}

\begin{abstract}
Ten crossbred barrows weighting $20 \mathrm{~kg}$ were allocated in five groups fed and on diets consisted of different total phosphorus $(\mathrm{P})$ levels: $0.30 \%, 0.40 \%, 0.51 \%, 0.65 \%$, and $0.73 \%$. The animals were intravenously injected $7.4 \mathrm{MBq}$ of radioactive $\mathrm{P}\left({ }^{32} \mathrm{P}\right)$ and after seven days they were slaughtered for further analysis. The evaluated parameters were intake, excretion, specific activities, and flow of $\mathrm{P}$ in compartments (1-gut, 2-blood, 3-bone, and 4-soft tissue). Besides fecal losses, the kidneys played an import role in $\mathrm{P}$ regulation. The flows of $\mathrm{P}$ from tissue and gut to the blood were affected by $\mathrm{P}$ intake.
\end{abstract}

Keywords: pig, metabolism, balance, true absorption, radio-phosphorus, kinetic

\section{RESUMO}

Foram usados 10 leitões machos castrados com média de peso vivo de 20kg, alojados em gaiolas metabólicas. $O$ delineamento experimental foi inteiramente ao acaso e os tratamentos consistiram em níveis de fósforo $(P)$ nas dietas: 0,30; 0,40; 0,51; 0,65 e 0,73\%. Os animais receberam injeção de 7,4 $\mathrm{MBq}$ de radiofósforo $\left({ }^{32} \mathrm{P}\right)$ e após sete dias foram abatidos para posteriores análises. As variáveis avaliadas foram: ingestão, excreção, atividades especificas e fluxo de $P$ nos compartimentos (1-trato digestivo, 2-corrente sanguínea, 3-tecidos moles e 4-ossos). Além das excreções fecais, os rins também representaram uma rota importante para a excreção do $P$. O fluxo de $P$ dos tecidos e trato digestivo para o sangue não foi afetado pelo consumo de P. O modelo proposto foi eficiente para avaliar o fluxo de $P$.

Palavras-chave: suíno, metabolismo, balanço, absorção verdadeira, radiofósforo, cinética

\section{INTRODUCTION}

Phosphorus (P) is the second most abundant mineral in the animal body. It is present as structural component (Symonds and Forbes, 1993) and it is involved in a wide variety of biochemical reactions (Ternouth, 1990).

Secretory and absorptive processes of $\mathrm{P}$ along the gastrointestinal tract substantially differ in ruminant and non-ruminant animals (Breves and
Schroder, 1991). In ruminants, large amount of $P$ is secreted into gut by salivary glands and this endogenous secretion is balanced by net $\mathrm{P}$ absorption in the small intestine. However, urinary $\mathrm{P}$ excretion is low and does not contribute to $\mathrm{P}$ homeostasis. In contrast, in nonruminants, salivary $\mathrm{P}$ concentration is lower but renal excretion plays an important function in $\mathrm{P}$ homeostasis.

Recebido em 25 de novembro de 2008

Aceito em 23 de março de 2009

*Autor para correspondência (corresponding author)

E-mail: japmoreira@bol.com.br 
A variety of techniques have been used to study $\mathrm{P}$ metabolism in domestic animals. These techniques differ from simple balance studies to more complex experiments involving cannulated animals or isolated organs. Fernandez (1995c), using combined results of balance studies and radioisotope kinetics, formulated and resolved a model of $\mathrm{P}$ metabolism for pigs to evaluate the nutritional implications of increasing $\mathrm{P}$ intake by pigs.

Experiments have been carried out using radioactive tracers to study the distribution of $P$ by means of compartimental models (Grace, 1981; Schneider et al., 1987; Teixeira et al., 2004; Dias, 2006; Vitti et al., 2006). Kinetics of ${ }^{32} \mathrm{P}$, following intravenous injection, was studied using a compartment analysis supported by a computer program (Boston et al., 1981).

In Brazil, $\mathrm{P}$ metabolism has been studied in pigs using the model proposed by Fernandez (1995c) and modified by Lopes (Lopes et al., 2001; Moreira, 2002; Moreira et al., 2004). However, there are information related to $\mathrm{P}$ metabolism in pigs using the model of Vitti et al. (2000).

In the present study, the hypothesis that $\mathrm{P}$ intake regulates $\mathrm{P}$ utilization and $\mathrm{P}$ flow in gut, blood, soft tissues, and bone was assumed. The isotopic technique by using labeled $\mathrm{P}$ allows the formulation of a model showing the biological flows of phosphorus.

The aim of this study was to evaluate the effects of $\mathrm{P}$ intake on $\mathrm{P}$ metabolism in pigs, by using isotope and balance techniques. A mathematical model for $\mathrm{P}$ metabolism in pigs is proposed.

\section{MATERIAL AND METHODS}

The research was performed at the Center for Nuclear Energy in Agriculture, at the Universidade de São Paulo, in Piracicaba, SP. Ten crossbred barrows, mean live weight $20 \mathrm{~kg}$, were housed in metabolic cages for a period of seven days for adaptation and another seven days for sampling (faeces, urine, and blood). Treatments consisted of: basal diet - treatment A - corn, soybean meal, and vitamin and mineral supplementation (except supplemental P), with $0.30 \%$ of total P. Adjustment of the total P in the other treatments was obtained by adding dicalcium phosphate to obtain the following total P levels: treatment B - $0.40 \%$; C $-0.51 \%$; D $0.65 \%$, and $\mathrm{E}-0.73 \%$ (Table 1). Phosphorus levels in the experimental diets were deficient in treatments $\mathrm{A}$ and $\mathrm{B}$, adequate in treatment $\mathrm{C}$, and in excess in treatments $\mathrm{D}$ and $\mathrm{E}$, according to NRC (Nutrient..., 1998). Feed was given twice a day.

Table 1. Ingredients and feed composition of diets with different phosphorus levels fed to pigs

\begin{tabular}{lccccc}
\hline Ingredient (kg) & $\mathrm{A}$ & $\mathrm{B}$ & $\mathrm{C}$ & $\mathrm{D}$ & $\mathrm{E}$ \\
& $(0.30 \% \mathrm{P})$ & $(0.40 \% \mathrm{P})$ & $(0.51 \% \mathrm{P})$ & $(0.65 \% \mathrm{P})$ & $(0.73 \% \mathrm{P})$ \\
\hline Corn & 84.80 & 83.46 & 82.17 & 81.86 & 82.14 \\
Soybean meal & 13.25 & 14.28 & 14.29 & 14.29 & 13.58 \\
Soybean oil & 0.50 & 0.60 & 0.70 & 0.80 & 1.10 \\
Calcium carbonate & 1.66 & 1.27 & 0.90 & 0.40 & 0.10 \\
Dicalcium phosphate & 0.00 & 0.52 & 1.05 & 1.75 & 2.18 \\
Common salt $^{\text {Vitamin mixture }}$ & 0.40 & 0.40 & 0.40 & 0.40 & 0.40 \\
Mineral mixture $^{2}$ & 0.40 & 0.40 & 0.40 & 0.40 & 0.40 \\
\hline Composition & 0.10 & 0.10 & 0.10 & 0.10 & 0.10 \\
\hline Crude protein (\%) & & & & & 13.79 \\
Ca (\%) & 13.37 & 13.76 & 14.11 & 14.09 & 0.60 \\
P (\%) & 0.60 & 0.60 & 0.60 & 0.60 & 0.73 \\
ME (Kcal/kg) & 0.30 & 0.40 & 0.51 & 0.65 & 3,415 \\
\hline
\end{tabular}

${ }^{1}$ Per kg of diet mixture - vitamins A: 1,750,000UI; $\mathrm{D}_{3}: 300,000 \mathrm{UI}$; E: 3,000mg; $\mathrm{K}_{3}: 400 \mathrm{mg} ; \mathrm{B}_{1}: 250 \mathrm{mg} ; \mathrm{B}_{2}$ : 750mg; $\mathrm{B}_{6}: 250 \mathrm{mg} ; \mathrm{B}_{12}: 300 \mu \mathrm{g}$; Niacin: 5,000mg; Pantothenic acid: 3,000mg; Coline: 3,000mg; Growth promoter: $12,000 \mathrm{mg}$; Antioxidant: 3,750.

${ }^{2}$ Per kg of diet mixture - Fe: 80,000mg; Cu: 12,000mg; Mn: 70,000 mg; Zn: 10,000; I: 1,000mg; Se: 120mg. Based on Rostagno et al. (1987). 
After seven days, pre-experimental period, each animal was intravenously injected with $7.4 \mathrm{MBq}$ of ${ }^{32} \mathrm{P}$ in $1 \mathrm{~mL}$ of sterile isotonic saline solution $(9 \mathrm{~g} / \mathrm{L}$ sodium chloride). Blood samples $(10 \mathrm{~mL})$ were taken at 24 hours intervals, after isotope administration, for seven days. Blood samples were centrifuged and plasm removed for analysis. Nine $\mathrm{mL}$ trichloroacetic acid $(100 \mathrm{~g} / \mathrm{L})$ was added to $1 \mathrm{~mL}$ plasm for protein precipitation. After centrifugation $(1,100 \mathrm{~g})$ inorganic $\mathrm{P}$ was determined by colorimetric analysis (Fiske and Subbarow, 1925).

Phosphorus intake, total faeces excretion weight, and urine volume were daily recorded and subsamples $(10 \%$ of total outputs) were stored for further analysis. Faecal samples (1g) were overnight dried $\left(105^{\circ} \mathrm{C}\right)$ and ashed $\left(500^{\circ} \mathrm{C}\right.$ for $8 \mathrm{~h})$. The ash was dissolved in concentrated $\mathrm{HCl}$ and the $\mathrm{P}$ concentration was determined by colorimetric method (Sarruge and Haag, 1974). Similar procedure was followed to determine the $\mathrm{P}$ concentration in food. Urine samples $(30 \mathrm{~mL})$ were dissolved in $12 \mathrm{~N} \mathrm{HCl}$, dried $\left(55^{\circ} \mathrm{C}\right)$, and ashed $\left(500^{\circ} \mathrm{C}\right)$. Ashes samples were diluted $(3 \mathrm{~N}$ $\mathrm{HCl}$ ) and volume was made up to $10 \mathrm{~mL}$. Inorganic $\mathrm{P}$ was determined using vanadatemolybdate reagents (Sarruge and Haag, 1974).

For radioactivity measurements, $1 \mathrm{~mL}$ plasma and $1 \mathrm{~mL}$ urine samples were added to $19 \mathrm{~mL}$ distilled water into counting vials. Ashed faecal samples (1g) were dissolved in $18 \mathrm{~N} \mathrm{H}_{2} \mathrm{SO}_{4}$ and placed into counting vials. Radioactivity of ${ }^{32} \mathrm{P}$ was measured in a Packard Liquid Scintillation Spectrometer (model 2450B) using Cerenkov radiation. Specific activities in plasma $\left(\mathrm{P}_{\mathrm{sap}}\right)$ and feces $\left(\mathrm{P}_{\text {saf }}\right)$ were determined as follows (Lofgreen and Kleiber, 1953; Salviano and Vitti, 1998):

$\mathrm{P}_{\text {sap }}=\mathrm{R}_{\mathrm{cpm}} / \mathrm{g} \mathrm{P}$

being $\mathrm{R}_{\mathrm{cpm}}$ the radioactivity count per minute measured by the equipment in $1 \mathrm{~mL}$ of plasma. Equation (1) also applies to specific activity measurement in $1 \mathrm{~g}$ of faeces.

At the end of the experimental period, pigs were slaughtered by intravenous injection of pentobarbital $(200 \mathrm{mg} / \mathrm{mL})$ and soft tissues (liver, heart, kidney, and longissimus dorsi muscle) and bone samples $\left(13^{\text {th }}\right.$ and $14^{\text {th }}$ ribs $)$ were collected.
Organs, muscle, and bone material were cleaned, weighed, and autoclaved. Samples were ground and dissolved in $18 \mathrm{~N} \mathrm{H}_{2} \mathrm{SO}_{4}$. The extract was transferred to vials for radioactivity determination. For mineral determination, bone samples were dissolved in concentrated $\mathrm{HCl}$ (Sarruge and Haag, 1974). Bone specific activity $\left(\mathrm{P}_{\mathrm{sab}}\right)$ in $1 \mathrm{~g}$ dry matter and ${ }^{32} \mathrm{P}$ incorporation $\left(\mathrm{P}_{\text {inc }}\right)$ in bone were calculated as follows:

$\mathrm{P}_{\mathrm{sab}}=\left(\mathrm{R}_{\mathrm{cpm}} / \mathrm{P}_{\text {inj }}\right) / \mathrm{g} \mathrm{P}$

(2) and

$\mathrm{P}_{\text {inc }}=\mathrm{P}_{\text {sab }}\left(\mathrm{P}_{\mathrm{t}}\right)$

being $\mathrm{P}_{\text {inj }}$ and $\mathrm{P}_{\mathrm{t}}$ the total dose injected and the total inorganic $\mathrm{P}$ in bone $(\mathrm{mg} / \mathrm{g} \mathrm{DM})$, respectively.

An isotope kinetics model based in Vitti et al. (2000) was used to describe $P$ metabolism in pigs (Fig. 1). Data were analyzed using multiple regression system by SAS/2000.

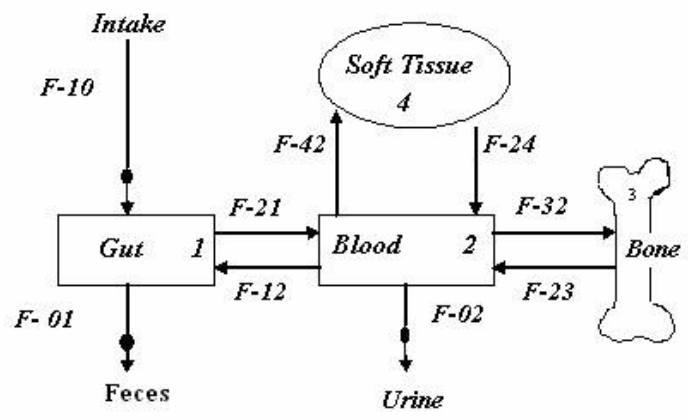

Figure 1. Diagrammatic representation of an isotope kinetic model of phosphorus metabolism in pigs.
$\mathrm{F}-12=\mathrm{s}_{1} \mathrm{~F}-10 /\left(\mathrm{s}_{2}-\mathrm{s}_{1}\right)$
$\mathrm{F}-21=\mathrm{F}-10+\mathrm{F}-12-\mathrm{F}-01$
(4),
$\mathrm{F}-32=\mathrm{s}_{3} \mathrm{Q}_{3} /\left[\mathrm{t}\left(\mathrm{s}_{2}-\mathrm{s}_{3}\right)\right.$
$\mathrm{F}-42=\mathrm{s}_{4} \mathrm{Q}_{4} /\left[\mathrm{t}\left(\mathrm{s}_{2}-\mathrm{s}_{4}\right)\right.$
(6),
(7),
$(\mathrm{F}-23+\mathrm{F}-24)=\mathrm{F}-02+\mathrm{F}-12+\mathrm{F}-32+\mathrm{F}-42-\mathrm{F}-21$ (8),
$\mathrm{F}-24=\left(\mathrm{s}_{3+4}-\mathrm{s}_{3}\right)(\mathrm{F}-23+\mathrm{F}-24) /\left(\mathrm{s}_{4}-\mathrm{s}_{3+4}\right)$
$\mathrm{F}-23=\mathrm{F}-23+\mathrm{F}-24-\mathrm{F}-24$
(10).

Table 2. Principal symbols used in the model

\begin{tabular}{|c|c|}
\hline $\mathrm{F}_{\mathrm{ij}}$ & $\begin{array}{l}\text { Total flux of } P \text { to pool } i \text { from } j ; F_{i 0} \\
\text { denotes an external flux into pool } I \text {, } \\
\text { and } F_{0 j} \text { a flux from pool } j \text { out of the } \\
\text { system. }\end{array}$ \\
\hline $\mathrm{Q}_{\mathrm{i}}$ & Total quantity of $\mathrm{P}$ in pool $\mathrm{i}: \mathrm{g}$ \\
\hline $\mathrm{q}_{\mathrm{i}}$ & Quantity of ${ }^{32} \mathrm{P}$ in pool i: dpm \\
\hline $\mathrm{S}_{\mathrm{i}}$ & $\begin{array}{l}\text { Specific activity of pool i (=qi/Qi): } \\
\mathrm{dpm} / \mathrm{g}\end{array}$ \\
\hline & Time: day \\
\hline SRA & Specific radioactive activity \\
\hline
\end{tabular}


The model assumes that (a) the gut pool is in both isotopic and non-isotopic steady states (b) and the plasma pool is in non-isotopic steady state.

\section{RESULTS}

Mean daily intake and daily excretion of $\mathrm{P}$, specific activities, and $\mathrm{P}$ concentrations in bone, blood, and soft tissues are summarized in Table 3. Dietary P levels (L) affected P intake (Pint) as expressed by the following equation:
Pint $=1.04 \mathrm{e}^{2.35 \mathrm{~L}}$
$r^{2}=0.95$
(11)

Phosphorus excreted in faeces $\left(\mathrm{P}_{\mathrm{F}}\right)$ and in urine $\left(\mathrm{P}_{\mathrm{U}}\right)$ were related to $\mathrm{P}$ intake:
$\mathrm{P}_{\mathrm{F}}=0.888 \mathrm{e}^{0.162 \mathrm{Pint}}$
$r^{2}=0.82$
$\mathrm{P}_{\mathrm{U}}=0.132 \mathrm{e}^{0.67 \text { Pint }}$
$\mathrm{r}^{2}=0.98$

Phosphorus excretion in faeces increased by $46.7 \%$ from the lowest to the highest $\mathrm{P}$ intake, and $\mathrm{P}$ concentration in urine increased by $90.5 \%$ from the lowest to the highest $\mathrm{P}$ intake.

The specific activity in faeces $\left(\mathrm{SA}_{\mathrm{F}}\right)$ decreased as dietary $\mathrm{P}$ increased. Similar response was observed in the specific activity in blood (SA blood $)$ :

$\mathrm{SA}_{\mathrm{F}}=7.41 \mathrm{e}^{-0.143 \text { Pint }} \mathrm{r}^{2}=0.60$

$\mathrm{SA}_{\text {blood }}=53.76 \mathrm{e}^{-0.105 \text { Pint }} \mathrm{r}^{2}=0.55$

Specific activity in bone and soft tissues were not affected by treatments, as well $\mathrm{P}$ concentrations in bone, tissues, and blood.

Table 3. Phosphorus intake levels, phosphorus excretion, specific activity, and other inputs used in pigs

\begin{tabular}{lcccccc}
\hline & \multicolumn{5}{c}{ Level of phosphorus intake } \\
\cline { 2 - 6 } & Symbol $^{*}$ & $\mathrm{~A}$ & $\mathrm{~B}$ & $\mathrm{C}$ & $\mathrm{D}$ & $\mathrm{E}$ \\
\hline $\begin{array}{l}\text { Input fluxes } \\
\text { (g of P/d) }\end{array}$ & & & & & \\
Intake & $\mathrm{F}-10$ & $1.88 \mathrm{~d}$ & $2.92 \mathrm{c}$ & $3.83 \mathrm{~b}$ & $4.55 \mathrm{~b}$ & $5.63 \mathrm{a}$ \\
Faeces & $\mathrm{F}-01$ & $1.25 \mathrm{~b}$ & $1.52 \mathrm{ab}$ & $1.33 \mathrm{~b}$ & $1.88 \mathrm{ab}$ & $2.35 \mathrm{a}$ \\
Urine & $\mathrm{F}-02$ & $0.05 \mathrm{ab}$ & $0.09 \mathrm{~b}$ & $0.18 \mathrm{ab}$ & $0.33 \mathrm{ab}$ & $0.53 \mathrm{a}$ \\
SRAs (cpm/g) & & & & & & \\
Faeces & $\mathrm{S}_{1}$ & $5.85 \mathrm{a}$ & $4.15 \mathrm{ab}$ & $5.55 \mathrm{a}$ & $3.35 \mathrm{~b}$ & $3.35 \mathrm{~b}$ \\
Blood & $\mathrm{S}_{2}$ & $50.0 \mathrm{a}$ & $38.5 \mathrm{~b}$ & $29.9 \mathrm{~b}$ & $31.4 \mathrm{~b}$ & $34.5 \mathrm{~b}$ \\
Bone & $\mathrm{S}_{3}$ & $21.8 \mathrm{a}$ & $19.3 \mathrm{a}$ & $16.9 \mathrm{a}$ & $18.3 \mathrm{a}$ & $20.0 \mathrm{a}$ \\
Soft tissues & $\mathrm{S}_{4}$ & $27.1 \mathrm{a}$ & $21.7 \mathrm{a}$ & $25.8 \mathrm{a}$ & $22.3 \mathrm{a}$ & $24.1 \mathrm{a}$ \\
Other inputs (g) & & & & & & \\
Blood P & $\mathrm{Q}_{2}$ & $0.06 \mathrm{a}$ & $0.07 \mathrm{a}$ & $0.07 \mathrm{a}$ & $0.07 \mathrm{a}$ & $0.07 \mathrm{a}$ \\
Bone P & $\mathrm{Q}_{3}$ & $54.8 \mathrm{a}$ & $52.9 \mathrm{a}$ & $55.2 \mathrm{a}$ & $48.6 \mathrm{a}$ & $40.3 \mathrm{a}$ \\
Soft tissues P & $\mathrm{Q}_{4}$ & $14.9 \mathrm{a}$ & $21.6 \mathrm{a}$ & $14.8 \mathrm{a}$ & $11.7 \mathrm{a}$ & $11.6 \mathrm{a}$ \\
\hline$*$ Symbor
\end{tabular}

*Symbols are according to figure 1 and are defined in Table 2.

Means in the same row followed by distinct letters are different $(\mathrm{P}<0.05)$.

Phosphorus outflow of each treatment, obtained according the kinetic model, is shown in Table. 4.

Table 4. Comparison of kinetic model outputs in pigs fed different $\mathrm{P}$ levels

\begin{tabular}{lcccccc}
\hline & \multicolumn{7}{c}{ Level of phosphorus intake } \\
\cline { 2 - 7 } & Symbol* & A & B & C & D & E \\
\hline Model output (g/d)) & & & & & & \\
& F-12 & $0.26 \mathrm{c}$ & $0.36 \mathrm{bc}$ & $0.87 \mathrm{a}$ & $0.55 \mathrm{abc}$ & $0.61 \mathrm{ab}$ \\
& F-21 & $0.89 \mathrm{c}$ & $1.76 \mathrm{~b}$ & $3.36 \mathrm{a}$ & $3.23 \mathrm{a}$ & $3.89 \mathrm{a}$ \\
& F-32 & $5.23 \mathrm{a}$ & $6.74 \mathrm{a}$ & $8.14 \mathrm{a}$ & $8.24 \mathrm{a}$ & $7.12 \mathrm{a}$ \\
& F-42 & $2.40 \mathrm{~b}$ & $3.46 \mathrm{ab}$ & $4.70 \mathrm{a}$ & $3.53 . \mathrm{ab}$ & $3.36 \mathrm{ab}$ \\
& F-24 & $1.92 \mathrm{~b}$ & $3.41 \mathrm{a}$ & $2.82 \mathrm{ab}$ & $2.30 \mathrm{ab}$ & $2.23 \mathrm{ab}$ \\
& F-23 & $5.13 \mathrm{a}$ & $5.39 \mathrm{a}$ & $7.70 \mathrm{a}$ & $7.12 \mathrm{a}$ & $5.50 \mathrm{a}$ \\
\hline
\end{tabular}

* Symbols are according to figure 1 and are defined in Table 2 .

Means in the same row followed by distinct letters are different $(\mathrm{P}<0.05)$. 
According to the model (Table 4) P flow from to blood to digestive tract (F-12) was increased with $\mathrm{P}$ intake exponentially with $\mathrm{P}$ intake $(\mathrm{P}<0.05)$ (equation 15) as well $\mathrm{P}$ from digestive tract to blood (F-21) (equation 16):

$\mathrm{F}-12=0.15$ (Pint) $)^{0.924} \mathrm{r}^{2}=0.64$

$\mathrm{F}-21=0.528 \mathrm{e}^{0.393 \text { Pint }} \mathrm{r}^{2}=0.85$

Phosphorus bone accretion (F-32) and bone resorption (F-23) were not influenced by $\mathrm{P}$ intake. Phosphorus mobilization from the blood to soft tissues (F-42) and $\mathrm{P}$ recycling from soft tissues (F-24) to blood increased with $\mathrm{P}$ intake, as expressed in the equations 17 and 18:

$\mathrm{F}-42=-0.365(\text { Pint })^{2}+2.967$ Pint $-1.90 \mathrm{r}^{2}=0.75$ (17)

F-24 $=-0.240(\text { Pint })^{2}+1.740$ Pint $-0.27 r^{2}=0.48$

(18).

\section{DISCUSSION}

The increased $\mathrm{P}$ flow across the digestive tract in response to increased $\mathrm{P}$ intake shows that the $\mathrm{P}$ absorption process was not saturated. According to Reinhardt et al. (1988), two processes are involved in the absorption of $\mathrm{P}$ : an active mechanism, which is easily saturated and a passive non-saturated process. The passive mechanism mainly occurs due to the high $\mathrm{P}$ concentration in the lumen of the tract which causes a high pressure towards the absorption sites.

The results of the present experiment showed that even at high $\mathrm{P}$ intake rates, the passive mechanism play an important role in $\mathrm{P}$ homeostasis. The increased $\mathrm{P}$ excretion in urine in response to $\mathrm{P}$ ingestion shows that, in nonruminant animals, the kidneys are an important route for regulating $\mathrm{P}$ homeostasis, besides $\mathrm{P}$ excretion in faeces (Cupák et al., 1972; Vipperman Junior et al., 1974; Georgievskii, 1982; Breves and Schröder 1991; Fernandez, 1995ab).

The decreased values of specific activity feces and blood was due to the dilution process of the radioactive material caused by the high $P$ inorganic concentration in those pools. In bone and soft tissues, inorganic $\mathrm{P}$ concentration did not change with $\mathrm{P}$ intake level as well as the specific activity in those compartments. The results are in agreement with literature (Fernandez, 1995b), that showed $\mathrm{P}$ accretion was constant and independent of the level of $\mathrm{P}$ intake. According to Fernandez (1995b), bone resorption is decreased with the increasing levels in $\mathrm{P}$ intake.

Bone resorption is dependent of the calcium and phosphorus levels in plasma. If the level of $\mathrm{Ca}$ in plasma is decreased, bone resorption is increased, in order to maintain stable the $\mathrm{Ca}$ level. Parathyroid hormone is the major regulator of $\mathrm{Ca}$ in plasma and its action depends on the presence of 1.25-dihydroxycholecalcipherol. Parathyroid hormone also affects $\mathrm{P}$ transport both in kidney and in gut (Furtado, 1991).

In the present study, despite the differences in $\mathrm{P}$ intake, the effect in bone resorption was not verified, due to the short experimental period (14 days) and the healthy conditions of the animals at the beginning of the experiment. When $\mathrm{P}$ resorption is compared to the total $\mathrm{P}$ absorbed $\left(\mathrm{F}_{23} / \mathrm{F}_{21}\right)$, it is observed that for low $\mathrm{P}$ intake, higher amount of $\mathrm{P}$ is mobilized from bone to the blood. This seems to be a mechanism to maintain $\mathrm{P}$ levels in plasma. The increased output of $\mathrm{P}$ from soft tissues when low $\mathrm{P}$ intake is low also contributes to maintain P levels in the blood for the normal functions of the animal body.

\section{CONCLUSIONS}

Faecal and urinary losses of phosphorus regulated $\mathrm{P}$ homeostasis in growing pigs. Interchanges of phosphorus from the digestive tract and soft tissues to the blood were related to $\mathrm{P}$ intake. Phosphorus intake had no influence on phosphorus mobilization in bone in growing pigs. The model formulated based on the use of radioisotopes was coherent with the biological flow of phosphorus in pigs.

\section{ACKNOWLEDGEMENTS}

We would like to thank Fundação de Amparo à Pesquisa do Estado de São Paulo (FAPESP Proc. 06/57574-5 and 04/14532-5) for financial support. 


\section{REFERENCES}

BOSTON, R.C.; GREIF, P.C.; BERMAN, M. Conversational SAAM-an interactive program for kinetics analysis of biological systems: Comput. Programs. Biomed., v.13, p.111-119, 1981.

BREVES, G.; SCHRÖDER, B. Comparative aspects of gastrointestinal phosphorus metabolism. Nutr. Res. Rev., v.105, p.125-140, 1991.

CUPÁK, M.; PROCHAZKA, Z.; JAMBOR, V. Utilization of phosphorus compounds in pigs after endogenous phosphorus determination by means of ${ }^{32}$ P. Acta Vet. Brno, v.41, p.257-262, 1972.

DIAS, R.S. Estudo do metabolismo do fósforo utilizando modelos matemáticos. 2006. $104 \mathrm{f}$. Tese (Doutorado) - Centro de Energia Nuclear na Agricultura, Universidade de São Paulo, Piracicaba, SP.

FERNANDEZ, J.A. Calcium and phosphorus metabolism in growing pigs. I. Absorption and balances studies. Livest. Prod. Sci., v.41, p.233241, 1995a.

FERNANDEZ, J.A. Calcium and phosphorus metabolism in growing pigs. II. Simultaneous radio-calcium and radium-phosphorus kinetics. Livest. Prod. Sci., v.41, p.243-254, 1995 b.

FERNANDEZ, J.A. Calcium and phosphorus metabolism in growing pigs. III. A model resolution. Livest. Prod. Sci., v.41, p.255-261, 1995c.

FISKE, C.H.; SUBBAROW, Y. The colorimetric determination of phosphorus. J. Biol. Chem., v.66, p.375-400, 1925.

FURTADO, M.O. Determinação $d a$ biodisponibilidade de fósforo em suplementos de fósforo para aves e suínos. 1991. 60f. Dissertação (Mestrado) - Escola de Veterinária, Universidade Federal de Minas Gerais, Belo Horizonte, MG.

GEORGIEVSKII, V.I. The physiological role of macroelements. In: GEORIGIEVSKII, V.I.; ANNENKOV, B.N.; SAMOLKIN, V.T. Mineral nutrition of animals. London: Butterworths, 1982. p.91-170.
GRACE, N.D. Phosphorus kinetics in sheep. Br. J. Nutr., v.45, p.367-374, 1981.

LOFGREEN, G.P.; KLEIBER, M. The availability of the phosphorus in alfalfa hay. $J$. Anim. Sci., v.12, p.366-371, 1953.

LOPES J.B.; VITTI, D.M.S.S.; ABDALLA et al. Modelo do fluxo biológico do fósforo de fontes de fosfato em suínos, usando o ${ }^{32} \mathrm{P}$ como marcador. Rev. Bras. Zootec., v.30, p.165-173, 2001.

MOREIRA, J.A. Radiofósforo nos estudos de biodisponibilidade e perdas endógenas, cinética nos tecidos e modelo biomatemático, associado ao desempenho de suínos alimentados com dietas contendo fitase. 2002. 142f. Tese (Doutorado) - Centro de Energia Nuclear na Agricultura, Universidade de São Paulo, Piracicaba, SP.

MOREIRA, J.A.; VITTI, D.M.S.S.; LOPES et al. Fluxo biológico do fósforo no metabolismo de suínos alimentados com dietas contendo fitase . Rev. Bras. Zootec., v.33, p.2066-2075, 2004.

NUTRIENT requirements of swine. 10.ed. Washington: National Academy, 1998. 190p.

REINHARDT, T.A.; HORST, R.L.; GOFF, J.P. Calcium, phosphorus and magnesium homeostasis in ruminants. Vet. Clin. N. Am.: Food Anim. Pract., v.4, p.331-350, 1988.

ROSTAGNO, H.S.; SILVA, D.J.; COSTA, P.M.A. et al. Composição de alimentos $e$ exigências nutricionais de aves e suínos: tabelas brasileiras. Viçosa: Imprensa Universitária. 1987. 59p.

SALVIANO, L.M.C.; VITTI, D.M.S.S. Influência da proporção de cálcio e fósforo na dieta nas perdas endógenas e na absorção de fósforo em ovinos. Pesq. Agrop. Bras., v.33, p.349-355, 1998.

SARRUGE, J.R.; HAAG, H.P. Análises químicas em plantas. Piracicaba: ESALQ/USP, 1974. 56p.

SCHNEIDER, K.M.; BOSTON, R.C.; LEAVER, D.D. Quantitation of phosphorus excretion in sheep by compartmental analysis. Am. J. Physiol., v.252, p.720-731, 1987.

SYMONDS, H.W.; FORBES, J.M. Mineral metabolism. In: FORBES, J.M.; FRANCE, J. 
(Eds). Quantitative aspects of ruminant digestion and metabolism. Wallingford: CAB International, 1993. p.363-379.

TEIXEIRA, A.O.; LOPES, D.C.; LOPES, J.B. et al. Determinação da biodisponibilidade do fósforo de diferentes fontes pela técnica de diluição isotópica, em suínos em crescimento. Rev. Bras. Zootec., v.33, p.1231-1237, 2004.

TERNOUTH, J.H. Phosphorus and beef production in Northern Australia. 3. Phosphorus in cattle: a review. Trop. Grassl., v.24, p.159169, 1990.

VIPPERMAN JÚNIOR, P.E.; PEO JÚNIOR, E.R.; CUNNINGHAM, P.J. Effect of dietary calcium and phosphorus level upon calcium, phosphorus and nitrogen balance in swine. $J$. Anim. Sci., v.38, p.758-765, 1974.

VITTI, D.M.S.S.; KEBREAB, E.; LOPES, J.B. et al. A kinetic model of phosphorus metabolism in growing goats. J. Anim. Sci., v.78, p.27062712, 2000.

VITTI, D.M.S.S.; ROQUE, A.P; DIAS, R.S. et al. Metabolismo de cálcio em ovinos em crescimento sob suplementação com diferentes fontes de cálcio: aplicação e comparação de dois modelos matemáticos. Rev. Bras. Zootec, v.35, p.2487-2495, 2006. 